\title{
Al-Ijarah dalam Perspektif Hadis; Kajian Hadis dengan Metode Maudhu'iy
}

\author{
Husain Insawan \\ Fakultas Ekonomi dan Bisnis Islam IAIN Kendari \\ E-mail:husain.insawan@gmail.com
}

\begin{abstract}
The purpose of this study was to discover the conception of al-Ijarah in the perspective of the hadith; and to know the quality of a hadith which discusses al-Ijarah by first doing naqd al-sanad, naqd al-mart, itibar hadith about trustworthiness and his muttabi'an, and giving syarh (explanation) intact about a representative hadith, so it can serve as a legal umbrella associated with al-Ijarah activities.

Using Takhrij al-Hadith bi al-Fazh and Takhrij al-Hadis bi al-Maudhu'iy, this study traces a number of hadiths and compiles them into a theme; then one of the reperesentative hadiths of the many hadiths that deal with al-Ijarah will be examined more broadly and deeply.

The translations of hadith that are deemed representative are: "Having said Abdullah, Abu Ishaq Ibn 'Isa said to me (Ahmad Ibn Hanbal): indeed Malik, from al-Zuhriy, from Ibn Muhayyashah, from his father (Sa'ad Ibn Muhayyashah); asked the permission of the Messenger of Allah to forbid the hunting, (Rasulullah) forbade the hiring, so he (Muhayyashah) did not ask again about it, until the Messenger of Allah said to him: "Feed your gardener and feed your brother".

After a search of the hadith narrated by Ahmad Ibn Hanbal (164-241 H) it is known that the hadith is classical ahadith ahad masyhur and qualified sahih based on the assessment of experts hadith that assess its sanad continued up to the Messenger of Allah. and the narrators of these traditions are fair, sabt (tsiqah), morals commendable, shaduq, ashah asanid, and a'lam al-nas. Thus, the hadith narrated by Ahmad Ibn Hanbal can be used as a legal umbrella on the activities of al-Ijarah by looking at the context in contemporary life.
\end{abstract}

Keywords: Al-Ijarah, hadits, sanad, matan, rawi, and legal protection. 


\begin{abstract}
Abstrak
Tujuan penelitian ini adalah untuk menemukan konsepsi al-Ijarah dalam perspektif hadis Nabi; dan untuk mengetahui kualitas suatu hadis yang membahas tentang al-Ijarah dengan terlebih dahulu melakukan naqd al-sanad, naqd al- matan, i'tibar hadis mengenai ke-syahidan dan ke-muttabi'an-nya, serta memberikan syarh (penjelasan) secara utuh tentang sebuah hadis yang representatif, sehingga dapat dijadikan sebagai payung hukum yang bertalian dengan kegiatan al-Ijarah.

Dengan menggunakan metode Takhrij al-Hadis bi al-Fazh dan Takhrij alHadis bi al-Maudhu'iy, penelitian ini melacak sejumlah hadis dan menghimpunnya dalam satu tema bahasan; kemudian salah satu hadis yang reperesentatif dari sekian banyak hadis yang membahas tentang al-Ijarah akan dikaji secara lebih luas dan mendalam.

Terjemahan hadis yang dianggap representatif itu adalah: "Telah berkata Abdullah; Abu Ishaq Ibn 'Isa berkata kepada-ku (Ahmad Ibn Hanbal); sesungguhnya Malik; dari al-Zuhriy; dari Ibn Muhayyashah; dari ayahnya (Sa'ad Ibn Muhayyashah); meminta izin kepada Rasulullah Saw. untuk menyewa pembekam, (Rasulullah) melarang menyewa pembekam itu, maka dia (Muhayyashah) tidak bertanya lagi mengenai hal itu, hingga Rasulullah berkata kepadanya: "berilah makan tukang kebun-mu dan berilah makan saudara-mu."

Setelah dilakukan penelusuran terhadap hadis yang diriwayatkan oleh Ahmad Ibn Hanbal $(164-241 \mathrm{H})$ tersebut diketahui bahwa hadis tersebut tergolong hadis ahad masyhur dan berkualitas sahih berdasarkan penilaian para ahli hadis yang menilai sanadnya bersambung hingga sampai kepada Rasulullah saw. serta para perawi hadis tersebut tergolong adil, sabt (tsiqah), akhlaknya terpuji, shaduq, ashah asanid, dan a'lam al-nas. Dengan demikian, hadis yang diriwayatkan Ahmad Ibn Hanbal dapat dijadikan sebagai payung hukum pada kegiatan al-Ijarah dengan melihat konteksnya dalam kehidupan kekinian.

Kata Kunci: Al-Ijarah, hadis, sanad, matan, rawi, dan payung hukum.
\end{abstract}

\section{A. Pendahuluan}

Zaman alaf baru ini dikenal dengan era perdagangan bebas yang muncul dalam berbagai program ekonomi yang menggiurkan dan akan melintasi batas-batas teritorial suatu wilayah di suatu negara. Negaranegara yang notabene muslim tidak bisa menghindar dari hal ini (Hofman, 2003).

Perdagangan baik dalam skala besar maupun kecil, merupakan bentuk transaksi yang melibatkan dua atau banyak pihak, yang sedikitbanyak tidak terlepas dari persoalan alIjarah dalam syariat Islam. 
Pemaknaan al-Jjarah berdasarkan perspektif hadis Nabi, cukup beragam adanya. Al-Ijarah dapat diterjemahkan sebagai sewa-menyewa, upah, dan atau pekerjaan. Hal ini cukup beralasan karena dalam konsep ekonomi yang berbasis syariah, transaksi atas obyek al-Ijarah mencakup dua bentuk, yakni transaksi menyangkut produksi dan transaksi yang berkaitan dengan jasa (service).

Dalam konteks seperti yang dilukiskan di atas, maka persoalan alIjarah pada akhirnya akan menjadi pelik karena sudah banyak melibatkan orang internal dan eksternal negeri, sehingga penjernihan atas dasar hukum seputar al-Ijarah adalah signifikan adanya. Pada tataran ini pula, klarifikasi dan klasifikasi atas Hadis Nabi dalam bentuk takhrij, itibar, naqd al-sanad dan naqd al-matan, syarah, dan natijah hadis Nabi (Ismail, 2003: 8385) merupakan suatu keharusan guna mendapatkan kualitas hadis yang diinginkan sehingga dapat dijadikan sebagai dasar hukum yang lebih rajih. Dari paparan tersebut di atas, maka permasalahan yang diajukan dalam makalah ini adalah: (1) Apa yang dimaksud dengan al-Ijarah dalam konteks hadis Nabi? (2) Bagaimana kualitas hadis tentang al-Ijarah? (3) Bagaimana pemahaman terhadap hadis-hadis tentang al-Ijarah?

\section{B. Konsep Dasar Al-Ijarah}

\section{Pengertian al-Ijarah}

Generik kata Ijarah berasal dari "ajru" yang terdiri dari susunan huruf alif,jim, dan $r a$ ' yang berarti "al-kirau 'ala al-'amali" (sewa atas suatu pekerjaan/upah kerja). Sedang kata Ijarah bermakna: "ma a'thaita min ajrin $f i$ al-'amal" (sesuatu yang engkau berikan atas suatu pekerjaan) (Zakariyyah, 1978: 62-63). Sedang secara terminologis, al-Ijarah berarti salah satu bentuk kegiatan muamalah dalam memenuhi kebutuhan hidup manusia, seperti sewa-menyewa, kontrak, dan lain-lain (Hoeve, 1997: 660).

Ada beberapa definisi al-Ijarah yang dikemukakan oleh para ulama fiqih: ulama mazhab Hanafi, mendefinisikan dengan "transaksi terhadap suatu manfaat dengan imbalan"; ulama mazhab Syafi'i mendefinisikan dengan "transaksi 
terhadap suatu manfaat yang dituju, tertentu, bersifat mubah, dan bisa dimanfaatkan dengan imbalan tertentu"; serta mazhab Maliki dan Hanbali, mendefinisikan dengan "pemilikan manfaat sesuatu yang dibolehkan dalam waktu tertentu dengan suatu imbalan".

Berdasarkan definisi tersebut di atas, maka akad al-Ijarah tidak boleh dibatasi oleh syarat. Akad al-Ijarah tidak berlaku pula pada pepohonan untuk diambil buahnya, karena buah itu sendiri adalah materi, sedangkan akad ijarah itu hanya ditujukan pada manfaat. Demikian juga halnya dengan kambing, tidak boleh dijadikan sebagai obyek ijarah untuk diambil susu atau bulunya, karena susu dan bulu kambing termasuk materi. Jumhur ulama fiqih juga tidak membolehkan air mani hewan ternak pejantan, seperti unta, sapi, kuda, dan kerbau, karena yang dimaksudkan dengan hal itu adalah untuk mendapatkan keturunan hewan, dan mani itu sendiri adalah materi. Hal ini sejalan dengan hadis Rasulullah: "Rasulullah Saw melarang penyewaan mani hewan pejantan". (HR. Bukhari, Ahmad Ibn Hanbal, al-
Nasai, dan Abu Daud; dari Abdullah Ibn Umar). Pada konteks ini, sewa rahim juga tidak dapat dibenarkan dalam Islam (Ahmad, 300-303). Demikian juga ulama fiqih tidak membolehkan ijarah terhadap nilai tukar uang, seperti dinar dan dirham, karena menyewakan hal itu berarti menghabiskan materinya; sedangkan dalam ijarah yang dituju hanyalah manfaat dari suatu benda.

Sementara di lain pihak, Ibn Qayyim al-Jauziah, ahli fiqih mazhab Hambali mengklaim bahwa pendapat jumhur ulama tersebut tidak didukung oleh al-Quran, sunnah, ijma', dan kias. Menurutnya, hal yang prinsip dalam syariat Islam adalah bahwa suatu materi yang berevolusi secara bertahap sama dengan manfaat, seperti buah pada pepohonan, serta susu dan bulu pada kambing. Ibn Qayyim menyamakan manfaat dengan materi dalam wakaf. Menurutnya, manfaat pun boleh diwakafkan, seperti memanfaatkan wakaf rumah untuk ditempati dalam waktu tertentu dan memanfaatkan hewan ternak untuk dimanfaatkan susunya. Tidak ada alasan yang melarang untuk 
menyewakan suatu materi yang hadir secara evolusi, sedangkan basisnya tetap utuh, seperti susu kambing, bulu kambing, dan manfaat rumah, karena kambing dan rumah tetap utuh.

\section{Rukun dan Syarat al-Ijarah}

Menurut ulama mazhab Hanafi, rukun al-Ijarah hanya satu, yaitu ijab (ungkapan menyewakan), dan qabul (persetujuan untuk sewa menyewa). Jumhur ulama mengatakan bahwa rukun al-Ijarah ada empat, yaitu orang yang berakad, sewa/imbalan, manfaat, dan sighah (ijab-qabul). Ulama mazhab Hanafi menyatakan bahwa orang yang berakad, sewa/imbalan, dan manfaat; termasuk syarat al-Ijarah, bukan rukunnya. Layaknya sebuah transaksi, maka ijarah dianggap sah apabila telah memenuhi rukun dan syarat al-Ijarah sebagai berikut: 1) Untuk kedua orang yang berakad, menurut mazhab Syafi'i dan Hanbali, disyaratkan sudah baligh dan berakal; 2) Kedua belah pihak yang berakal menyatakan kerelaannya untuk melakukan akad alIjarah; 3) Manfaat yang menjadi obyek al-Ijarah harus diketahui secara sempurna sehingga tidak muncul perselisihan di kemudian hari; 4) Obyek al-Ijarah itu bisa diserahkan dan dipergunakan secara langsung serta tidak bercacat; 5) Obyek al-Ijarah tersebut sesuatu yang dihalalkan oleh syara; 6) Yang disewakan itu bukan suatu kewajiban bagi penyewa; 7) Obyek ijarah itu merupakan suatu yang biasa disewakan; 8) Upah/sewa dalam akad ijarah harus jelas, tertentu, dan yang bernilai harta; dan 9) Ulama mazhab Hanafi berpendapat bahwa upah/sewa itu sejenis dengan manfaat yang disewa (Hove, 661-662).

\section{Macam-macam al-Ijarah}

Dilihat dari segi obyeknya, akad al-Ijarah ulama fiqih membaginya ke dalam dua macam, yaitu: al-Ijarah yang bersifat manfaat dan al-Ijarah yang bersifat pekerjaan. Ijarah yang bersifat manfaat, seperti sewa-menyewa rumah, toko, kendaraan, pakaian, dan perhiasan. Apabila manfaat itu merupakan manfaat yang dibolehkan syariat untuk dipergunakan, maka ulama fiqih sepakat menyatakan boleh dijadikan obyek sewa-menyewa. Ijarah yang bersifat pekerjaan ialah dengan cara mempekerjakan seseorang untuk 
melakukan suatu pekerjaan, apabila jenis pekerjaan itu jelas, seperti buruh bangunan, tukang jahit, buruh pabrik, tukang sepatu, dan lainnya. Ijarah seperti ini, ada yang bersifat pribadi, misalnya menggaji seorang pembantu rumah tangga; dan yang bersifat serikat, yaitu seseorang atau sekelompok orang yang menjual jasanya untuk kepentingan orang banyak, seperti tukang jahit dan buruh pabrik (Heve: 662-663).

\section{Berakhirnya Akad al-Ijarah}

Al-Ijarah akan menjadi batal (fasakh) bila terjadi hal-hal sebagai berikut: 1) Cacat barang sewaan yang kejadian itu terjadi pada tangan penyewa; 2) Rusaknya barang yang disewakan, seperti rumah menjadi runtuh; 3) Rusaknya barang yang diupahkan (majur 'alaih), seperti baju yang diupahkan untuk dijahitkan; 4) Terpenuhinya manfaat yang diakadkan, berakhirnya masa yang telah ditentukan, dan selesainya pekerjaan; 5) Menurut Hanafiyah, boleh fasakh ijarah dari salah satu pihak, seperti yang menyewa untuk dagang, kemudian dagangannya ada yang mencuri, maka ia dibolehkan untuk memfasakh-kan sewaan itu (Suhendi, 2002: 122).

\section{Takhrij Al-Hadis}

\section{Klasifikasi Tanawwu'al-Hadis}

Dalam menelusuri teks hadis mengenai al-Ijarah, penulis melakukan takhrij al-hadis dengan menggunakan metode Takhrij al-hadits bi al-alfazh dan Takhrij al-hadits bi al-maudhu'iy (alMuhdi: 23-306). Cara kerja metode yang pertama dilakukan dengan melacak kosa kata al-Ijarah dalam almu'jam. Dalam konteks ini, terdapat 13 buah hadis yang menyangkut kata alIjarah; dan secara keseluruhan mencapai 129 buah dengan segenap kata jadiannya. Sedangkan cara kerja metode yang kedua adalah menghimpun sejumlah hadis yang membahas tentang tema yang sama; lalu melakukan analisis terhadap sebuah hadis yang representative dalam berbagai hal dan selanjutnya mengambil kesimpulan. Berikut ini akan disajikan sebagian hadis-hadis yang berkenaan dengan al-ijarah, yaitu:

a. Ahmad Ibn Hanbal dalam kitabnya Musnad Ahmad Ibn Hanbal (Hanbal, 435): 


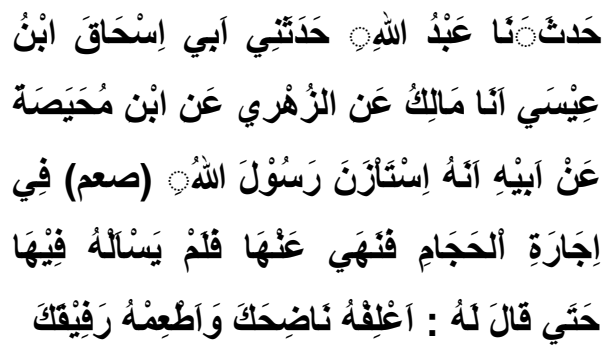

"Telah berkata Abdullah; Abu Ishaq Ibn 'Isa berkata kepada-ku (Ahmad Ibn Hanbal); sesungguhnya Malik; dari alZuhriy; dari Ibn Muhayyashah; dari ayahnya (Sa'ad Ibn Muhayyashah); meminta izin kepada Rasulullah Saw. untuk menyewa pembekam, (Rasulullah) melarang menyewa pembekam itu, maka dia (Muhayyashah) tidak bertanya lagi mengenai hal itu, hingga Rasulullah berkata kepadanya: "berilah makan tukang kebun-mu dan berilah makan saudara-mu."

b. Al-Bukhariy dalam kitabnya Shahih al-Bukhariy (Al-Bukhariy: 1992: 70):

"Dari Abu Musa ra., dari Nabi SAW bersabda: "Perbandingan orang Yahudi dan Nasrani dengan Kaum Muslimin, seumapama orang yang mengupah satu kaum. Mereka bekerja untuk orang itu satu hari penuh sampai malam dengan upah tertentu. Tetapi setelah mereka bekerja setengah hari, mereka berkata: Kami tidak butuh upah yang telah Anda janjikan untuk kami. Dan apa yang Kami kerjakan, semuanya batal. Kata si pengupah kepada mereka, "Janganlah kamu berbuat begitu. Selesaikanlah sisa pekerjaannmu dan ambillah upah secukupnya." Mereka menolak dan meninggalkan pekerjaan mereka. Kemudian si pengupah mengupah dua orang upahan sesudah mereka, dan berkata kepada keduanya, "Sempurnakanlah sisa harimu ini, untukmu upah yang telah saya janjikan kepada mereka." Merekapun bekerjalah. Setelah tiba waktu Ashar, keduanya berkata, "Apa yang telah kami kerjakan batal. Untuk Andalah upah yang Anda janjikan kepada Kami." Kata si pengupah, "Sempurnakanlah sisa pekerjaanmu, karena sisa yang tinggal itu hanya sedikit saja. Tetapi keduanya menolak. Maka si pengupah mengupah satu kaum untuk mengerjakan sisa hari mereka. Lalu bekerjalah mereka hingga matahari terbenam. Sesudah itu mereka menerima upah mereka, meliputi upah kedua golongan yang telah mendahului mereka tadi. Begitulah perumpamaan mereka dan hasil yang mereka terima dari cahaya (petunjuk) ini."

Hadis tersebut di atas berkualitas sahih mengingat Bukhari sebagai mukharrij yang memiliki kualitas hadis yang tidak diragukan. Adapun makna ijmaliy yang dikandung oleh hadis tersebut yakni menjelaskan tentang kontrak atas pekerjaan antara pengupah dengan buruh yang berasal dari tiga kaum. Kaum pertama adalah orang Yahudi, kaum kedua adalah Nasrani, dan kaum ketiga adalah Islam. Hadis ini bisa bermakna analogi atas agama yang dianut yaitu Islam yang hadir kemudian sebagai agama yang 
menyempurnakan ajaran agama Yahudi dan Nasrani.

c. Ibn Majah dalam kitabnya Sunan Ibn Majah (Majah, 1995: 20.):

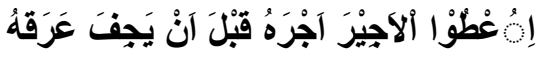

"Berikanlah olehmu upah orang sewaan (buruh) sebelum keringatnya kering."

Hadis ini menjelaskan bahwa pekerjaan apapun yang sudah dikerjakan hendaknya diberikan upahnya sesegera mungkin, tanpa haus ditunda-tunda lagi. Para pekerja ingin langsung menikmati hasil keringatnya setelah menyelesaikan suatu pekerjaan. Hadis ini menurut jumhur ulama berkualitas sahih.

d. Al-Nasai dalam kitabnya Sunan alNasai:

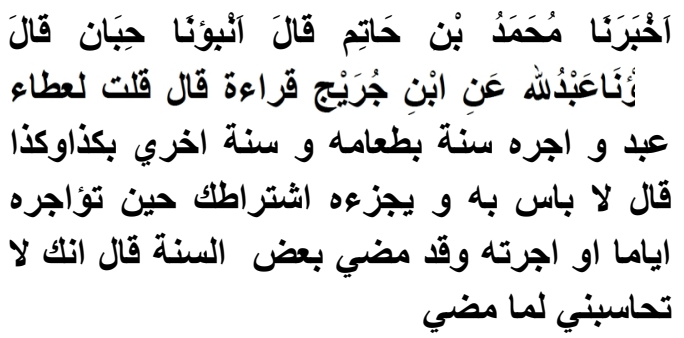

"Dari Ibn Juraij bahwa saya berkata kepada Atha'mengenai seorang buruh yang upahnya setahun dengan (ditanggung) makan dan setahun yang lain dengan upah sekian, Ia(Atha') berkata: "Tidak apa engkau menempuh cara itu dan buruh itu memenuhi syarat yang engkau tetapkan, sehingga engkau dapat mengupahnya satu hari lalu memberinya upah. Dan apabila buruh itu meninggal pada pertengahan tahun, maka (kata Atah') engkau membayar upah atas pekerjaan yang telah ia selesaikan."

Demikian pula dengan hadis ini berkualitas sahih, yang menjelaskan tentang mekanisme pengupahan yang berkaitan dengan waktu dan volume pekerjaan. Buruh atau pekerja bisa dibayar pertahun atau perhari sesuai kontrak yang telah disepakati, dengan ditanggung makan atau tidak sesuai dengan volume pekerjaan yang telah dikerjakan, dan pembayaran upah dilakukan di akhir pekerjaan, sehingga walalupun pekerja itu sudah meninggal maka masih bisa dihitung upah perharinya.

e. Imam Malik dalam kitabnya AlMuwaththa (Anas, 1989: 646):

"Mewartakan kepadaku Malik dari Ibn Syihab, dari Ibn Muhayyashah anl-Anshariy salah seorang Bani Haritsah: Sesungguhnya ia bertanya kepada Rasulullah SAW mengenai sewa pembekam, maka Rasul melarangnya dan Ia tidak melanjutkan pertanyaannya lagi hingga Rasulullah bersabda: "Berilah makan tukang kebunmu yaitu saudaramu."

f.Abu Daud dalam kitabnya Sunan Abu

Daud (al-Sijistaniy, 1952: 136.):

"Mewartakan kepada kami Abdullah Ibn Musallamah al-Ka'nabiyu, dari Malik, dari Ibn Syihab, dari Ibn Muhayyasha, dari ayahnya: Sesungguhnya ia bertanya kepada Rasulullah SAW mengenai sewa pembekam, 
maka Rasul melarangnya dan Ia tidak melanjutkan pertanyaannya, dan meminta izinnya lagi hingga Rasulullah memerintahkan kepadanya: "Berilah makan tukang kebunmu dan saudaramu."

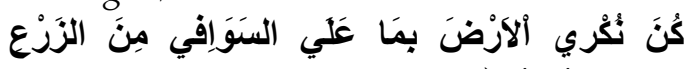

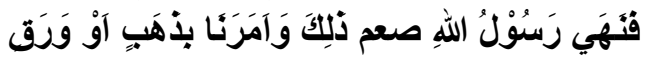

"Dahulu kami menyewa tanah dengan jalan membayar dari tanaman yang tumbuh. Lalu Rasulullah melarang kami (menggunakan) cara itu dan memerintahkan kami agar membayarnya dengan uang emas atau perak."

Hadis yang diriwayatkan oleh Imam Malik dan Abu Daud semakna dengan hadis Ahmad Ibn Hanbal. Namun satu hadis lainnya yang diriwayatkan oleh Abu Daud menjelaskan tentang al-ijarah sebagai sewa-menyewa tanah yang dilarang jika pembayarannya melalui hasil tanaman yang tumbuh di atas tanah tersebut karena dikhawatirkan tanaman itu tidak mampu membuahkan hasil maksimal sehingga akan menimbulkan kerugian. Sebagai solusinya Nabi menegaskan agar sewamenyewa tanah hendaknya dibayar dengan mata uang dinar/emas atau dirham/perak).

Oleh karena hadis yang dikemukakan di atas nampaknya tanawwu,' maka sanad hadis yang di- i'tibar dan dikritik di sini hanya satu saja, yakni hadis yang di-takhrij oleh Ahmad Ibn Hanbal seperti yang tersebut di atas yang menggunakan satu jalur sanad saja. Meskipun terdapat pula dua buah hadis yang memiliki redaksi matan yang hampir sama diriwayatkan oleh Malik Ibn Anas dan Abu Daud.

\section{Naqd al-Hadis}

a. I'tibar al-Hadis

Hadis di atas hanya di-takhrij oleh seorang mukharrij (Ahmad Ibn Hanbal dan jalur sanadnya hanya satu. Kegiatan selanjutnya ialah melakukan I'tibar. Kegiatan ini sangat berguna untuk mengetahui keadaan sanad hadis seluruhnya dilihat ada atau tidak adanya pendukung (corroboration) berupa periwayat yang berstatus muttabi (Ahmad, 87) atau syahid (Ibid). Dengan dilakukannya I'tibar maka akan terlihat dengan jelas seluruh jalur sanad hadis yang diteliti, nama-nama periwayatnya, dan metode periwayatan yang digunakan masing-masing periwayat yang bersangkutan. Untuk mempermudah proses I'tibar hadis mengenai al-Ijarah ini, maka penulis 
hanya membuat skema sanad hadis sebagai berikut:

\section{Skema Hadis Ahmad Ibn Hanbal tentang}

al-Ijarah

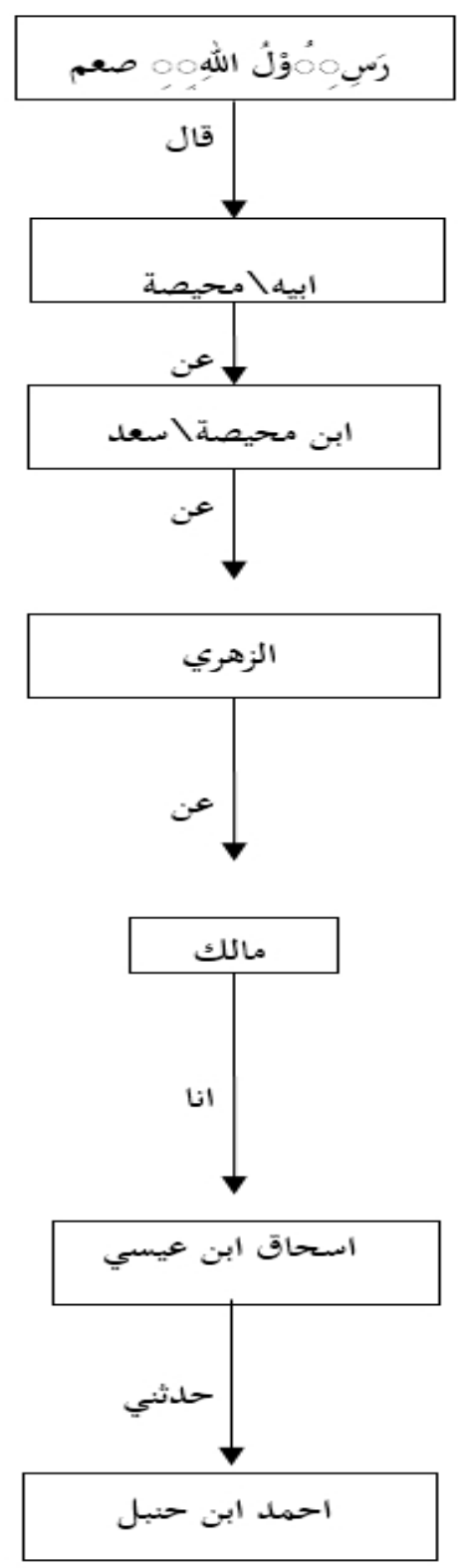

Dari skema hadis di atas terlihat bahwa hadis yang bersangkutan ditakhrij oleh seorang mukharrij, yakni Ahmad Ibn Hanbal. Dengan demikian, jika dilihat dari segi kuantitatif perawinya, maka hadis tersebut tergolong hadis ahad (al-Thahhan, 1979: 22-29).

\section{b. Naqd al-Sanad}

Ahmad Ibn Hanbal (164-241 H)

Abu Abdillah Ahmad Ibn Muhammad Ibn Hanbal Ibn Hilal Ibn Asad al-Syaibani Abu Abdillah alMarwaniy al-Baghdadiy (Baghdadiy, 441-442), lahir di kota Baghdad tahun 164 H. dan wafat pada hari Jumat 12 Rabi'ul Awal 241 H. di tempat kelahirannya. Ayahnya meninggal dunia ketika beliau berumur lima tahun. Dalam hidupnya beliau tergolong miskin, namun tidak menghalangi untuk belajar sehingga guru-gurunya sangat banyak. Beliau menerima hadis antara lain dari Abd al-Rahman Ibn Mahdiy, Abdullah Ibn Numairal-Hamdaniy, Waqi', Hasyim Ibn Basyir, Muhammad Ibn Ja'far, Ishaq Ibn Isa, dan lainnya.Sedangkan muridnya adalah Bukhari, Muslim, Abu Dawud, dan lainlain (Al-Mizziy, 227-230). Imam Ahmad juga tergolong sebagai imam mazhab yang besar pengaruhnya. Di masa tuanya beliau dikucilkan oleh pemerintah 
Sultan al-Ma'mun al-Mu'tashim alWatsiq yang beraliran Mu'tazilah. Bahkan dijadikan sebagai aliran resmi negara ketika itu, sehingga mengakibatkan Imam Ahmad berkalikali dipenjara sampai pada masa alMutawakkil, karena menolak konsep pemakhlukan al-Quran itu baru.

Ulama kritikus hadis menilai bahwa Imam Ahmad sebagai tokoh muhaddis yang berkredibilitas tinggi. Mereka antara lain: 1) Al-Qasim: tidak ada orang yang datang kepada saya melebihi Ahmad, dia adalah hiasan umat di bidang Ilmu Hadis; 2) Ibn Ma'in (158-233 H): saya tidak melihat orang yang sebaik Ahmad; 3) Al-Syafi'i (W. 204 H): saya keluar ke Baghdad dan saya tidak menemukan orang yang lebih faqih, zuhud, wara', dan 'alim selain dari pada Ahmad; 4) Al-Nasa'i: Ahmad itu tsiqah ma'mun; 5) AlQaththan (W. 198 H): tidak ada orang yang datang kepada saya melebihi kebaikannya Ahmad, dia adalah hiasan umat di bidang Ilmu Hadis (AlAsqalaniy, 67); 6) Jumhur ulama menilainya sebagai periwayat yang 'adil, sabt (tsiqah), dan tidak ditemukan kekurangan yang beliau miliki (AlDzahabiy, 431).

Tampaknya tidak ada ulama kritikus hadis yang mencela diri Ahmad Ibn Hanbal, bahkan penilain akan keterpujiannya berada pada tingkat yang tinggi dan tertinggi. Dengan demikian, kualitas dan kapabilitas Ahmad Ibn Hanbal dalam periwayatan hadis tidak diragukan lagi.

\section{Ishaq Ibn Isa (140-214 H)}

Nama lengkapnya Ishaq Ibn Isa Ibn Nujaih al-Baghdadiy Abu Ya'kub Ibn al-Thabba'. Dalam meriwayatkan hadis ia belajar kepada Malik, alHammadyn, Syuraik Ibn Abdullah, Ibn Luhayah, Hasyim, Jarir Ibn Hazim dan lain-lain. Beliau mempunyai murid di antaranya Ahmad, Abu Khaitsamah, alDarimiy, Ya'kub Ibn Syaibah, Muhammad Ibn Rafi, dan lain-lain. Para ulama kritikus hadis menilai: l) Bukhari: Ishaq Ibn Isa adalah masyhur al-hadis; 2) Shalih Ibn Muhammad: la ba'sa bihi shaduq; 3) Abu Hatim: Ishaq itu shaduq (Al-Asqalaniy, 157).

Malik (93-179 H)

Nama lengkapnya Malik Ibn Anas Ibn Malik Ibn Abi 'Amir Ibn 
'Amru Ibn al-Haris ibn 'Utsman. Ia adalah Imam Madinah dan Imam Mazhab Maliki. Beliau berguru kepada 'Amir Ibn Abdullah, Nu'aim Ibn Abdullah, Zaid Ibn Aslam, Nafi', Humaid al-Thawil, Shafwan Ibn Salim, Abu al-Zinad, Abdullah Ibn Dinar, dan lainnya. Murid-muridnya antara lain al-Zuhriy, Yahya Ibn Sa'id, al-Anshariy, Yazin Ibn Abdullah, al-Tsauriy, Ibn Juray, Ishaq Ibn Isa al-Tabba', Bisyr Ibn Umar al-Zahraniy, dan lainnya.

Para ulama kritikus hadis memberikan penilaian: 1) Bukhariy: Malik termasuk rangkaian ashah alasanid, yaitu dari Malik, dari Nafi', dari Umar; 2) Yahya Ibn Ma'in: semua guru Malik (periwayat tempat Malik menerima hadis) siqah kecuali Abd alKarim; 3) Abdullah Ibn Ahmad: saya bertanya kepada ayahku (Ahmad Ibn Hanbal), siapakah sahabat al-Zuhriy yang paling sabit, beliau menjawab Malik sabit dalam segala hal. Ditemukan banyak sekali pujian yang ditujukan kepada Malik dan dianggap paling sabit dari dua Sufyan (Ibn Uyyanah dan Ibn Sa'ad al-Tsauriy) (AlAsqalaniy, 350-353).

\section{Al-Zuhriy (50-125 H)}

Nama lengkapnya Muhammad Ibn Muslim Ibn 'Ubaidillah Ibn Abdillah Ibn Syihab Ibn Abdillah Ibn al-Harits Ibn Zuhrah Ibn Qilab Ibn Murrah al-Qaraisyi al-Zuhriy alMadaniy (Al-Asqalaniy, 385).

Guru-gurunya dalam periwayatan hadis adalah Abdullah Ibn Umar Ibn al-Khattab, Abdullah Ibn Ja'far, Rabi'ah Ibn 'Ubad, al-Masuruh Ibn Mukhramah, Abd al-Rahman Ibn Azhar, Abdullah Ibn Amir, Sahal Ibn Sa'ad, Malik Ibn Anas al-Hadatsaniy, Abdullah Ibn Muhairiz, dan lain-lain (Al-Asqalaniy, 385). Murid-muridnya adalah Atha' Ibn Abi Rabah, Muammar al-Laits al-Qusha'i, dan Malik Ibn Anas (al-Raziy, 71-72).

Penilaian ulama hadis terhadap al-Zuhriy di antaranya: 1) Ibnu Sa'ad: al-Zuhriy adalah tsiqah, banyak hadisnya, luas ilmunya sekaligus sebagai faqih; 2) Abu al-San'ad: Dia adalah orang yang paling luas ilmunya (a'lam al-nas); 3) Amr Ibn Dinar: tidak ada orang yang lengkap hadisnya selain dari al-Zuhriy; 4) Umar Ibn Abd alAziz: tidak ada orang yang sunnah kecuali al-Zuhriy; 5) Ayyub: saya tidak pernah melihat seorang yang lebih luas 
pengetahuannya dari pada al-Zuhriy;

6) Sufyan: tidak ada orang yang lebih mengetahui hadis Nabi pada masa ini kecuali al-Zuhriy. Tidak ada kritikus hadis yang mencela pribadi al-Zuhriy, bahkan mereka mengemukakan pujian yang tertinggi yakni tsiqah.

\section{Ibn Muhayyashah}

Nama lengkapnya Sa'ad Ibn Muhayyashah, ia menerima hadis dari Nabi dan dari ayahnya. Ia tergolong mursal karena hadis-hadis yang diterima sebagian langsung dari Nabi. Murid-muridnya antara lain Haram Ibn Sa'ad (anaknya), Abu Daud, Abd al-Razzaq, Ma'mar, dan al-Zuhriy.

Para kritikus hadis memberikan penilaian kepada Sa'ad Ibn Muhayyashah, seperti Abd alRazzaq menyatakan bahwa ia tidak menerima atau tidak mengikuti hadis yang lain, selain dari Sa'ad Ibn Muhayyashah (Al-Asqalaniy, 419-420).

\section{Abu Muhayyashah}

Sebagaimana anaknya, Abu Muhayyashah tergolong sahabat yang menerima hadis secara langsung dari Nabi. Dalam hal ini, prototipe dari Abu Muhayyashah sudah terwakili oleh anaknya Sa'ad Ibn Muhayyashah. Oleh karena Abu Muhayyashah termasuk dari kelompok sahabat, maka kapasitas diri dan derajat kesahihan hadisnya tidak diragukan lagi, mengingat kaidah yang menyatakan "kullu shahabatin 'udul" (setiap sahabat tergolong adil). Sebagai kejelasan atas kapasitas sanad hadis ini, maka berikut ditampilkan skema perawiperawinya:

Tabel Sanad Hadis al-Ijarah Ahmad Ibn Hanbal:

\begin{tabular}{|l|c|c|l|}
\hline N a m a & R a w i & S a n a d & Kapasitas Kepribadian \\
\hline Abu Muhayyashah & I & VI & Jumhur ulama: 'adil \\
Sa'ad Ibn Muhayyashah & II & V & Abd al-Razzaq: 'adil \\
Al-Zuhriy & III & IV & Jumhur ulama: tsiqah \\
Malik Ibn Anas & IV & III & $\begin{array}{l}\text { Jumhur ulama: paling tsabit } \\
\text { Ishaq Ibn 'Isa }\end{array}$ \\
Ahmad Ibn Hanbal & V & II & $\begin{array}{l}\text { Abu Hatim: shaduq Bukhari: } \\
\text { mashur al-hadis }\end{array}$ \\
& Mukharrij & I & Jumhur ulama: 'adil dan \\
& & & tsiqah \\
\hline
\end{tabular}


c. Naqdal-Matan

Untuk menentukan kualitas kesahihah matan hadis tentang alIjarah di atas, maka terdapat beberapa tolak ukur yang dijadikan sebagai kriteria ke-maqbul-an suatu hadis, yakni: a) Hadis tersebut tidak bertentangan dengan akal sehat; b) Tidak bertentangan dengan hukum alQuran yang telah muhkam; c) Tidak bertentangan dengan hadis mutawatir; d) Tidak bertentangan dengan amalan yang telah menjadi kesepakatan ulama masa lalu (ulama salaf); e) Tidak bertentangan dengan dalil yang telah pasti; dan f) Tidak bertentangan dengan hadis ahad yang kualitas kesahihannya sangat kuat (Ahmad, 163).

Hadis yang menjelaskan tentang pelaksanaan al-Ijarah yang telah disyariatkan, tidak bertentangan al-Quran, sejalan dengan pesannya dalam surat al-Thalaq ayat 6 :

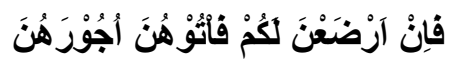
"Jika mereka telah menyusukan anakmu, maka berilah upah mereka".

Dalam surat al-Qashash ayat 26, dijelaskan pula bahwa:

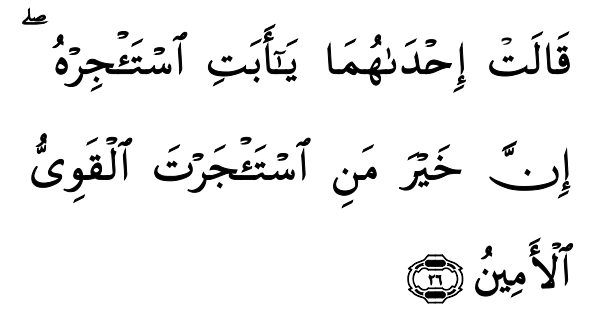

26. Salah seorang dari kedua wanita itu berkata: "Ya bapakku ambillah ia sebagai orang yang bekerja (pada kita), karena Sesungguhnya orang yang paling baik yang kamu ambil untuk bekerja (pada kita) ialah orang yang kuat lagi dapat dipercaya".

Demikian pula, hadis di atas tidak bertentangan dengan hadis yang lebih sahih, seperti yang diriwayatkan oleh Bukhari dan Muslim:

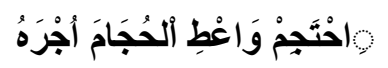

"Berbekamlah kamu, kemudian berikanlah olehmu upahnya kepada tukang bekam itu." (HR. Bukhari Muslim).

Dengan mengacu pada kriteria matan hadis tersebut di atas dan dengan pertimbangan sanad yang dimiliki oleh hadis tentang al-Ijarah ini, maka dapat disimpulkan bahwa matan hadis tersebut berkualitas hasan lidzatihi karena perawinya berada pada thabaqat/tingkatan keempat, yakni shaduq. 


\section{Syarh al-Hadis}

a. Matan hadis:

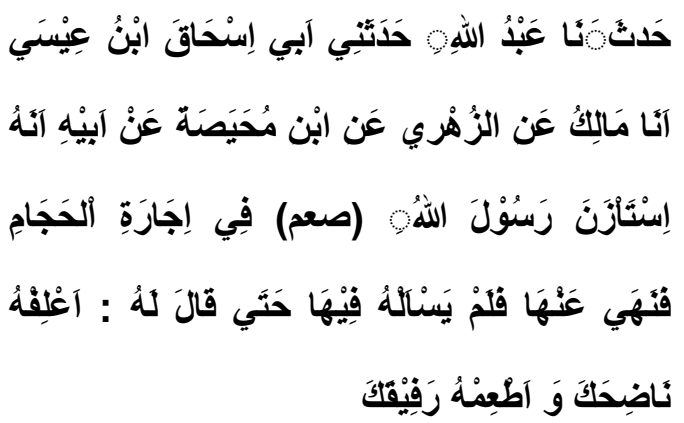

Arti hadis:

"Telah berkata Abdullah; Abu Ishaq Ibn 'Isa berkata kepada-ku (Ahmad Ibn Hanbal); sesungguhnya Malik; dari al-Zuhriy; dari Ibn Muhayyashah; dari ayahnya (Sa'ad Ibn Muhayyashah); meminta izin kepada Rasulullah Saw. untuk menyewa pembekam, (Rasulullah) melarang menyewa pembekam itu, maka dia (Muhayyashah) tidak bertanya lagi mengenai hal itu, hingga Rasulullah berkata kepadanya: "berilah makan tukang kebun-mu dan berilah makan saudara-mu."

b. Fiqh al-hadis:

Hadis tersebut di atas menjelaskan tentang sewa-menyewa pembekam yang sempat dipertanyakan oleh Abu Muhayyashah, tetapi Rasulullah melarang untuk menyewa pembekam, jika masih ada orang yang lebih dekat dengan Abu Muhayyashah untuk dijadikan pembekam lain, yaitu tukang kebun yang ia miliki atau saudara (teman)nya. Rasulullah sengaja mengutarakan itu kepada Abu
Muhayyashah agar ia lebih memanfaatkan orang yang lebih dekat dengan dirinya. Dari pada uang yang jadi upah itu diberikan kepada orang lain, lebih baik diberikan kepada orang-orang terdekat yang lebih membutuhkan.

Makna filosofis yang dapat ditangkap dari hadis tersebut ialah memberdayakan materi kepada sanakkeluarga dan karib-kerabat yang lebih memerlukan, jauh lebih baik dari pada memberdayakan materi kepada orang lain. Perlakuan seperti ini bukan bermaksud untuk menyuburkan nepotisme, tetapi lebih merupakan implementasi atas nilai-nilai kepekaan sosial terhadap lingkungan yang melingkupi. Pertimbangan lain yang bisa diterima ialah bahwa harta yang digunakan oleh Abu Muhayyashah adalah harta milik pribadinya sendiri sehingga mekanisme yang ditempuh untuk memberdayakan harta itu dapat saja dilakukannya. Berbeda halnya jika harta atau sesuatu itu miliki negara atau umum maka penggunaannya harus berdasarkan pertimbangan kepentingan umum dan masyarakat 
bisa mengambil bagian dalam pengelolaan harta tersebut.

Semakin jelas lagi menyangkut mekanisme pemberdayaan harta itu karena al-Quran juga memberikan isyarat mengenai hal ini, bahwa harta itu lebih utama diberikan kepada yang lebih berhak dan yang lebih dekat kekerabatannya (fakir, miskin, ibnu sabil dst.) dengan pemberi harta tersebut. Hal ini dilakukan dengan pertimbangan bahwa orang-orang tersebut sudah dikenal oleh pemberi harta, sehingga pemberian tersebut tidak akan salah alamat. Ikatan ukhuwah yang selama ini telah terbangun akan semakin kukuh dengan adanya pemberdayaan itu.

\section{Al-Ijarah dalam Konteks Kekinian}

Konsep dan praksis al-ijarah dewasa ini semakin berkembang pesat mengingat semakin maju pula agregasi ekonomi manusia. Al-ijarah banyak ditemukan setiap saat dan tempat pada berbagai bidang kehidupan manusia. Contoh sederhana misalnya, bidang jasa konstruksi, didapati perusahaan yang disewa oleh seorang pengusaha dalam rangka mengikuti dan memenangkan tender proyek pada suatu instansi. Demikian pula dengan perusahaan lain yang telah mendapatkan surat perintah kerja yang disertai surat kontrak kerja untuk membangun. Kegiatan ini sudah biasa dilakukan, yang didahului dengan suatu akad/perjanjian yang disepakati bersama, tanpa ada pihak yang dirugikan.

Pada skala besar, bisa saja pengusaha asing menyewa perusahaan domestik dalam rangka perniagaan di Indonesia. Kegiatan perniagaan baru bisa berjalan jika sudah tercapai kesepakatan bersama antara pengusaha dengan pemilik perusahaan. Hal ini masuk kategori ijarah yang bersifat manfaat, karena terdapat perusahaan yang memberikan jasa persewaan untuk dimanfaatkan.

Dalam bidang pendidikan agama, seseorang menyewa guru mengaji untuk mengajar secara privat kepada anaknya, yang terlebih dahulu membuat komitmen mengenai besarnya upah dan waktu untuk menerima upah yang akan diberikan. Langkah ini ditempuh oleh seorang yang berkeluarga sebagai bentuk 
tanggung jawab keluarga terhadap pendidikan anak guna membentuk akhlak dan pengetahuan anak terhadap ajaran agamanya. Aktivitas ini termasuk al-ijarah yang bersifat pribadi karena menyangkut privacy seseorang dalam urusan rumah tangganya. Selanjutnya, di bidang perbankan yang menerapkan manajemen syariat Islam mempunyai salah satu produk yang disebut sewa (ijarah) dan sewa-beli(ijarah wa iqtina). Bank bertindak sebagai pemilik barang dan nasabah sebagai penyewa. Penyewa dapat diberi opsi untuk memiliki barang yang disewakan pada saat sewa selesai. Inilah yang dimaksud dengan ijarah wa iqtina atau ijarah muntahiyah bi tamlik. ${ }^{1}$

\section{E. Kesimpulan}

1. Al-Ijarah merupakan bentuk muamalah antara dua pihak atau lebih yang berkaitan dengan sewa-menyewa atau upahmengupah baik menyangkut jasa maupun produksi.

2. Kegiatan al-ijarah dapat dilakukan

${ }^{1}$ Zainul Arifin, Dasar-Dasar Manajemen Bank Syariah, (Cet. I, Jakarta: Alvabet, 2002), h. 28. apabila telah memenuhi ketentuan syara mengenai rukun dan syaratnya, sebaliknya akan terjadi pembatalan (fasakh) jika terdapat pelanggaran dalam rukun dan syaratnya.

3. Memberdayakan sanak-keluarga atau karib-kerabat dalam kegiatan al-ijarah jauh lebih utama dari pada orang lain dengan pertimbangan bahwa harta tersebut adalah milik pribadi. Sangat berbeda jika harta itu milik negara, ia mesti digunakan dan dikelola demi kepentingan masyarakat umum dan masyarakat bisa berpartisipasi untuk memberdayakannya.

\section{DAFTAR PUSTAKA}

Al-Quran al-Karim

Al-Adlabi, Shalah al-Din Ibn Ahmad, AlManhaj Naq al-Matan, (Beirut: Dar alAfaq al-Jadidah, 1983).

Al-Asqalaniy, Ahmad Ibn Ali Ibn Hajar, Nuzhah al-Nazhar Syarkh Nukhbah alFikr, (Cet. II, Kairo: al-Istiqamah, 1368 H.).

, Tahzib al-Tahzib, (Jilid I, Cet. I, Beirut: Dar al-Fikr, 1994) 
Al-Baghdadi, Abu Bakr Ahmad Ibn Ali Tsabit al-Khathib, Kitab al-Kifayah fi 'Ilmal Riwayah, (Mesir: Mathba'ah alSa'adah, 1972). , Tarikh Baghdad, (Juz IV, Madinah: Al-Maktabah al-Salafiyah, t.th.).

Al-Bukhariy, Shahih al-Bukhariy, (Juz III, Cet. I, Beirut: Dar al-Fikr, 1992).

Al-Dzahabiy, Abu Abdillah Syamsuddin Muhammad, Tadzkirah al-Huffadz (Jilid II, Cet. II, Beirut: Dar al-Ihya al-Tiran al-Anbiy, t. th.).

Ahmad, Arifuddin, Prof. Dr. Muhammad Syuhudi Ismail: Paradigma Baru Memahami Hadis Nabi, (Cet. I, Jakarta: Insan Cemerlang, 2003).

Al-Mizziy, Jamal al-Din Abi al-Hajjaj Yusuf, Thazib al-Kamal fi Asma'I alRijal, (Juz I, Beirut: dar al-Fikr, 1994)

Al-Raziy, Abd al-Rahman Ibn Abi Harun, Kitab al-Jarh wa al-Ta'dil, (Juz II, Cet. I, Haidrabat: Majlis Dairah alMa'arif, 1952).

Al-Sijistaniy, Abu Daud Sulaiman Ibn Asy'ats. Sunan Abu Daud, (Juz II, Cet. I, Beirut: Dar al-Fikr, 1952).

Al-Suyuthi, Jalal- al-Din Abd al-Rahman Ibn Abi Bakr Thabaqat al-Huffadz, (Beirut: Dar al-Kutub al-'Ilmiyyah, 1983).

Al-Thahhan, Mahmud. Ushul al-Takhrij wa Dirasah al-Asanid, diterjemahkan oleh
Ridwan Nasir dengan judul Metode Takhrij dan Penelitian Sanad Hadis, (Cet. I, Surabaya: Bina Ilmu).

Arifin, Zainul. Dasar-Dasar Manajemen Bank Syariah, (Cet. I, Jakarta: Alvabet, 2002).

Hendi Suhendi, Fiqh Muamalah: Membahas Ekonomi Islam, (Cet. I, Jakarta: RajaGrafindo Persada, 2002).

Hoffman, Murad Wilfried, Bangkitnya Agama, (Cet. I, Jakarta: Serambi, 2003).

Ibn Hanbal, Ahmad, Al-Musnad al-Imam Ahmad Ibn Hanbal, (Beirut: Dar alFikr, t.th.).

Ibn Majah, Muhammad Ibn Yazid alQauzaiyniy, Sunan Ibn Majah, (Juz II, Beirut: Dar al-Fikr, 1995).

Ibn Malik, Anas, Al-Muwaththa, (Cet. I, Beirut: Dar al-Fikr, 1989).

, Taisir Musthalah al-Hadits, (Cet. II, Beirut: Dar al-Quran al-Karim, 1979).

Ibn Zakariyyah, Abi Husain Ahmad Ibn Faris, Maqayis al-Lughah, (Juz I, Beirut: Da al-Fikr, 1979)

Van Hoeve, Ensiklopedi Hukum Islam, (Juz II, Cet. I, Jakarta: Ikhtiar Baru, 1997) 